\title{
RELATIONSHIP BETWEEN THE URANIUM CONCENTRATION AND THE UPGRADING OF EL-SIBAEYA PHOSPHATE ORE BY NEW PHYSICAL PROCESSES.
}

\author{
El-Shennawy, A. A.* \\ * Nuclear Materials Authority, P. O. Box: 530 El-Maadi, Cairo, Egypt.
}

\begin{abstract}
Phosphate plays a significant economic role in developing countries because the phosphate rock is consumed in the agricultural sector as fertilizers and animal feedstocks as well as used in the manufacture of high-grade phosphoric acid used in the manufacture used in pharmaceuticals, detergents, food products and other industrial uses. So, this research focus is represented in how to apply some new physical concentration processes derived from ore dressing to arise the concentration of $\mathrm{P}_{2} \mathrm{O}_{5}$ (21.14\%) in sample of $10 \mathrm{Kg}$ of low grade Egyptian phosphate ore was collected from East El-Sibaeya region as an alternative method to the existing calcination method, which is not friendly environment and has several disadvantages and accordingly the find relationship between the uranium concentration and the upgrading of El-Sibaeya phosphate ore. Upgrading the phosphate ore is done through crushing, screening, up current Classifiers, gravimetric separation and hydraulic separation. The results of this study led to achieve the desired product (high grade of phosphate) which is imperative to meeting market requirements, and at optimum conditions gave a product which analyzed $\mathrm{P}_{2} \mathrm{O}_{5}$ (33.63\%), $\mathrm{CaO}(47.66 \%), \mathrm{MgO}$ (0.57\%), $\mathrm{SiO}_{2}$ (4.91\%), $\mathrm{NaO}_{2}(0.49 \%)$, $\mathrm{K}_{2} \mathrm{O}(0.89 \%), \mathrm{Al}_{2} \mathrm{O}_{3}(0.64 \%), \mathrm{Fe}_{2} \mathrm{O}_{3}(1.25 \%)$ and $\mathrm{U}(172.12 \mathrm{ppm})$.
\end{abstract}

\section{Keywords}

Phosphate ore, crushing, screening, up current classifiers, gravimetric separation and hydraulic separation.

\section{INTRODUCTION}

Phosphate rock is the only commercially feasible source for the production of phosphorus fertilizers and elemental phosphorus. About $95 \%$ of the produced phosphates are consumed in the agricultural sector as fertilizers and animal feedstocks. The world annual phosphate production in 2012 is around 217 million tons, and the global reserves amount to 67 billion tons. Egypt has about $4 \%$ of the world phosphate reserve (2.78 billion tons) and produces about 3 percent of the world phosphate production (about 6 million t/y). Geologically, the economic phosphate beds belong to the central facial zone of the upper senonian age (upper Cretaceous and lower Eocene) deposits. Several studies suggest that phosphate rock reserves could be depleted within 50-100 years (Steen, 1998, Dehaes et at., 2009, Smil et at., 2009; Vaccari, 2009; Cordell, 2010) while others are more optimistic (Van kauwenbergh, 2010; Van Vaccariren et al, 2010). The distribution of reserves, which was already thought to be significantly concentrated wilt just five countries in control of $86 \%$ of global reserves (Jasinski 2010), was further intensified with the release of the IFDC report, and its subsequent revision to USGS estimates. The latest estimates, now suggest that few countries control the world phosphate reserves wilt morocco alone controls $74.6 \%$ of global reserves with 5.0 billion tones, china 5.5\% with 3.7 billion tons and Algeria $3.3 \%$ 
with 2.2 billion tons (Jasinski, 2011). The rest of the world share only $16.6 \%$ of the world phosphate reserves, which amounts to 11.1 billion tons. At east Sibaeya, the phosphate ore (figure 1) used to be crushed and attrition washed to remove the clayey fine fraction (about 10-12\% by weight, assaying about 12-18\% $\mathrm{P}_{2} \mathrm{O}_{5}$ ).

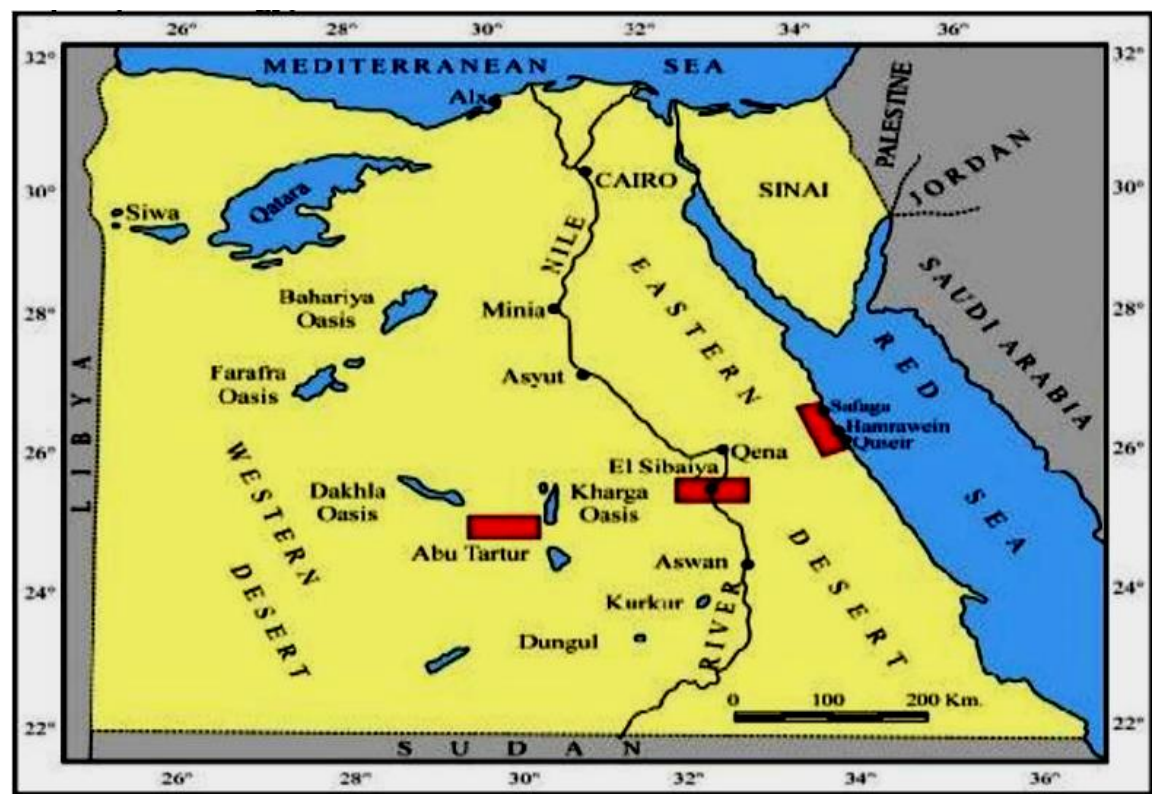

Fig. 1: Location map of the phosphate deposits in Egypt.

\section{MAterial ANd MethodS}

\subsection{Material}

$10 \mathrm{Kg}$ of a low-grade Egyptian phosphate Sample from the east Sibaiya region was used for this Study. Chemical composition of the studied phosphate sample is determined by using XRD analysis.

\subsection{Methods}

Several beneficiation techniques for upgrading phosphate ore were applied in the present study.

\subsubsection{Crushing and screening}

This is the first step to dissociate the phosphate ore and liberate the minerals and other constituent ${ }^{[2,3,4,10]}$. The hammer mill used to crush the ore and then the product of the crusher flows on vibrating screen to separate the fraction, which is more than 100 mesh.

\subsubsection{Up current classifiers}

Up current classifiers is used for mechanically cleaning and removing all the Slimes ( Kaolinite ) and fine quartz from the sample which act on the differences in the size and density of mineral particles. ${ }^{(1,10,11)}$ Just enough water was injected through perforated spray pipes and both the mechanical stirrer of $1 \mathrm{HP}$ and stirring speed $200 \mathrm{rpm}$ are adjustable (figure 2). Then the cleaned sample was dried and subjected to concentration by gravimetric separation and the tailing (slimes and low-density mineral grains) was filtered, dried, weight and bagged for analysis. 


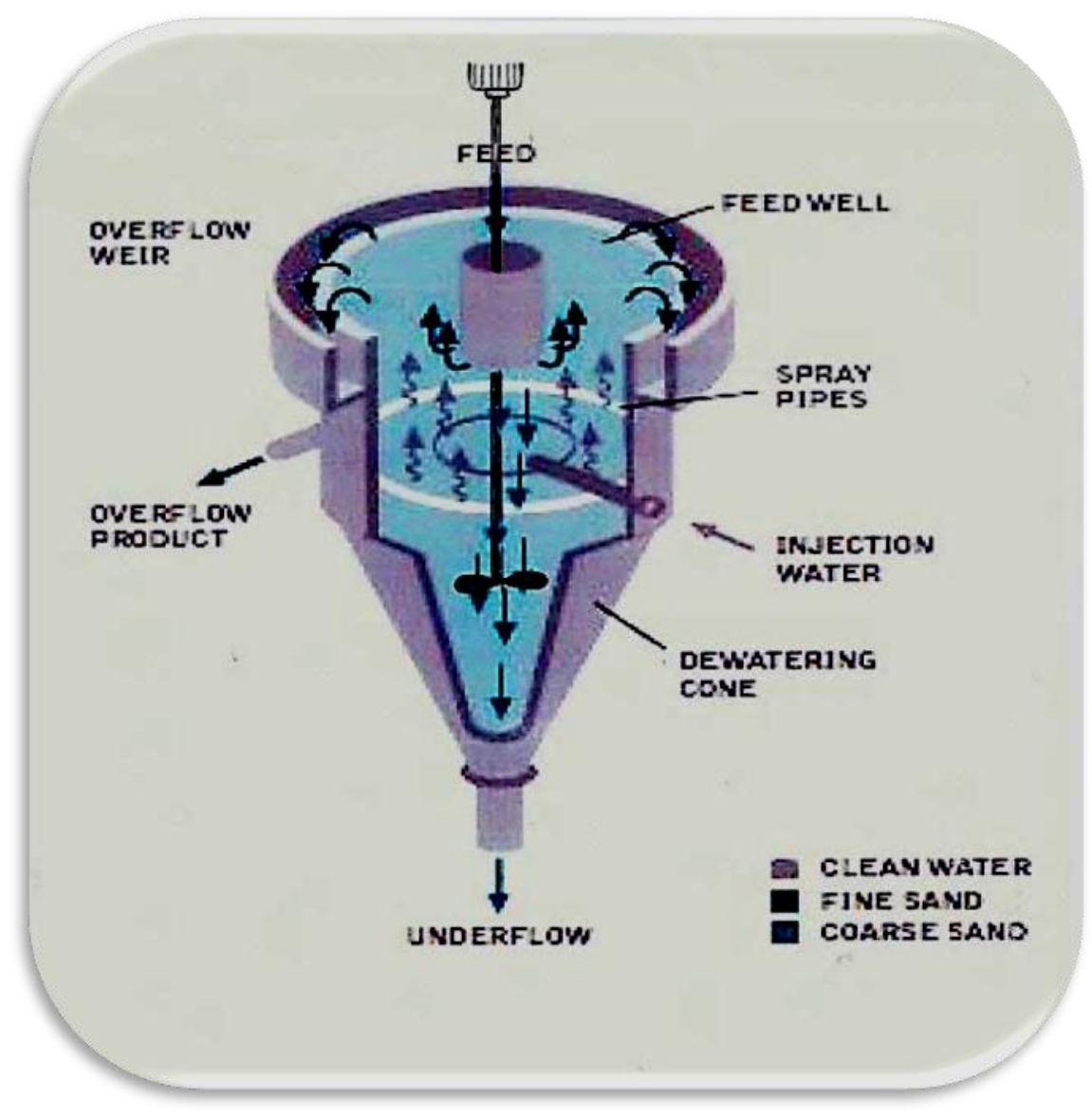

Fig. 2: Longitudinal section of up-current classifiers.

\subsubsection{Gravimetric separation}

The shaking table concentrator is used to concentrate $\mathrm{P}_{2} \mathrm{O}_{5}$ in the cleaned sample which coming from the previous step, which act on the difference of specific gravity between the important minerals and the gangue ${ }^{(5,6,7,8,9,11)}$. The separated materials were obtained under the optimum conditions, particle size was less than 150 mesh (100 um ), The optimal deck slop of the shaking table was 10 , the optimal feed water flow rate was 8 liters per minute The concentrate phosphate sample was dried weight and bagged for analysis.

\subsubsection{Hydraulic separation}

In this process we used the hydraulic classifier (designed by El-Shennawy, A. A.) to promote the concentration of $\mathrm{P}_{2} \mathrm{O}_{5}$ of the sample which coming from the previous step. The hydraulic classifier is used to separate the solid particles into two or more products according to their velocities when falling through a fluid medium. Generally, water is used as fluid medium. Velocities of particles depend on their size, shape and density. Particles with higher density and large size will settle down quickly as compared with particles with lower density and smaller size. The water injected through each of glass unit can be adjusted (figure 3a, b). As a result of using the hydraulic classifier, three grades of the concentrate phosphate sample were obtained as in the following flow sheet showing the separation steps for upgrading of El-Sibaeya phosphate ore as in figure 4. 

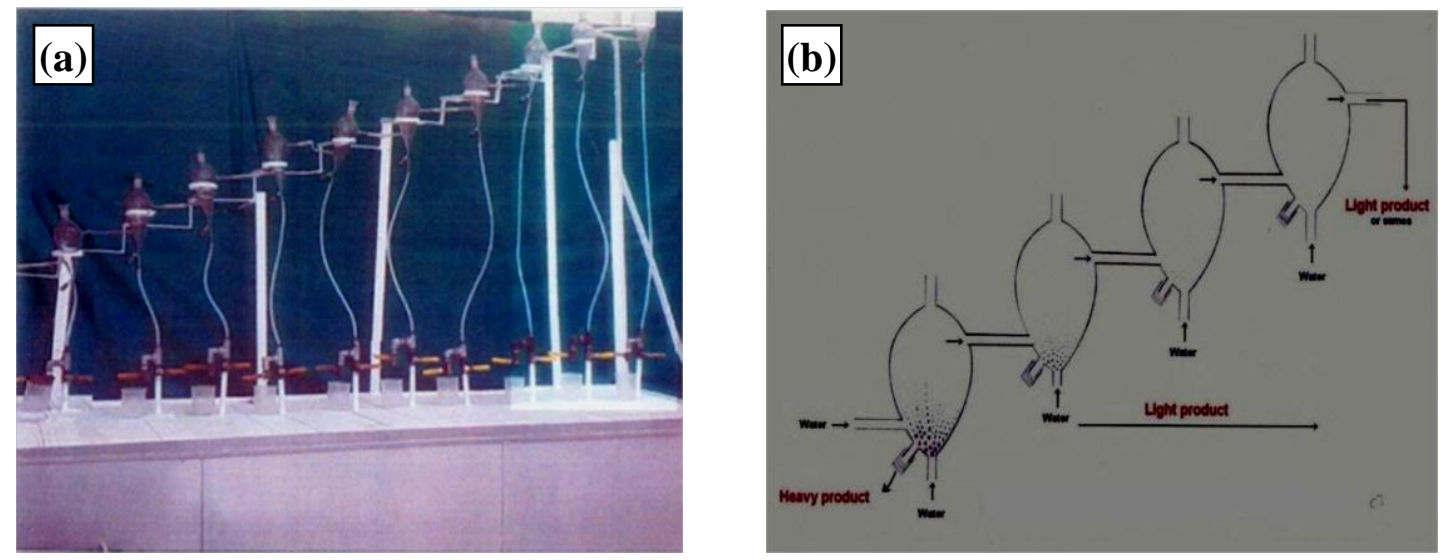

Fig. 3: (a) Hydraulic separation device, (b) Principle of hydraulic classifier.

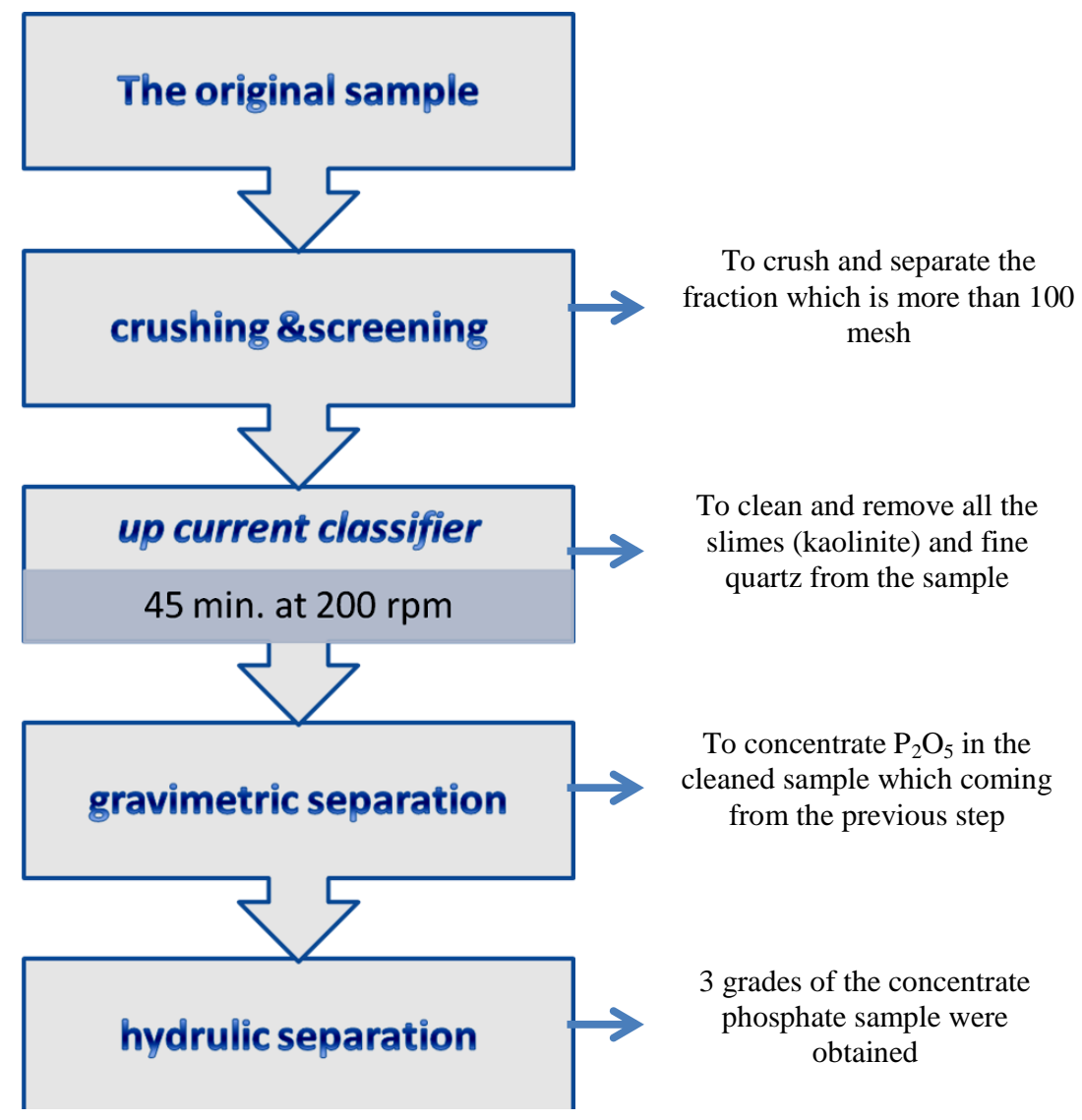

Fig. 4: A simplified flow sheet showing the separation steps for upgrading of ElSibaeya phosphate ore. 


\section{RESULTS AND DISCUSSIONS}

The sample was subjected to XRD analysis as shown in figure 5 before investigation of the physical processes to concentrate $\mathrm{P}_{2} \mathrm{O}_{5}$ in a sample of low-grade Egyptian phosphate ore was collected from East El-Sibaeya region. The XRD pattern of examined low grade phosphate sample indicates that, apatite $\left(\mathrm{Ca}_{10}\left(\mathrm{PO}_{4}, \mathrm{CO}_{3}\right)_{6}(\mathrm{~F}, \mathrm{OH})_{2}\right)$ is the predominant phosphate mineral, whereas calcite $\left(\mathrm{CaCO}_{3}\right)$ is the main carbonate gangue mineral associating the ore with some dolomite $\mathrm{CaMg}\left(\mathrm{CO}_{3}\right)_{2}$ mineral. In addition, the sample was analyzed by means of XRF as shown in figure 6. It has shown that phosphate ore contains Si (19.48\%), P (9.23\%), Ca (60.97\%), Mn (0.38\%), Fe (8.81\%), $\mathrm{Zn}(0.12 \%)$, and $\mathrm{Sr}(0.65 \%)$. In addition, the sample was analyzed for its major oxides and trace elements constituents before starting the upgrading experiments. The results of chemical analysis of the sample can be seen in table 1, which show that sample is not imperative to meeting market requirement.

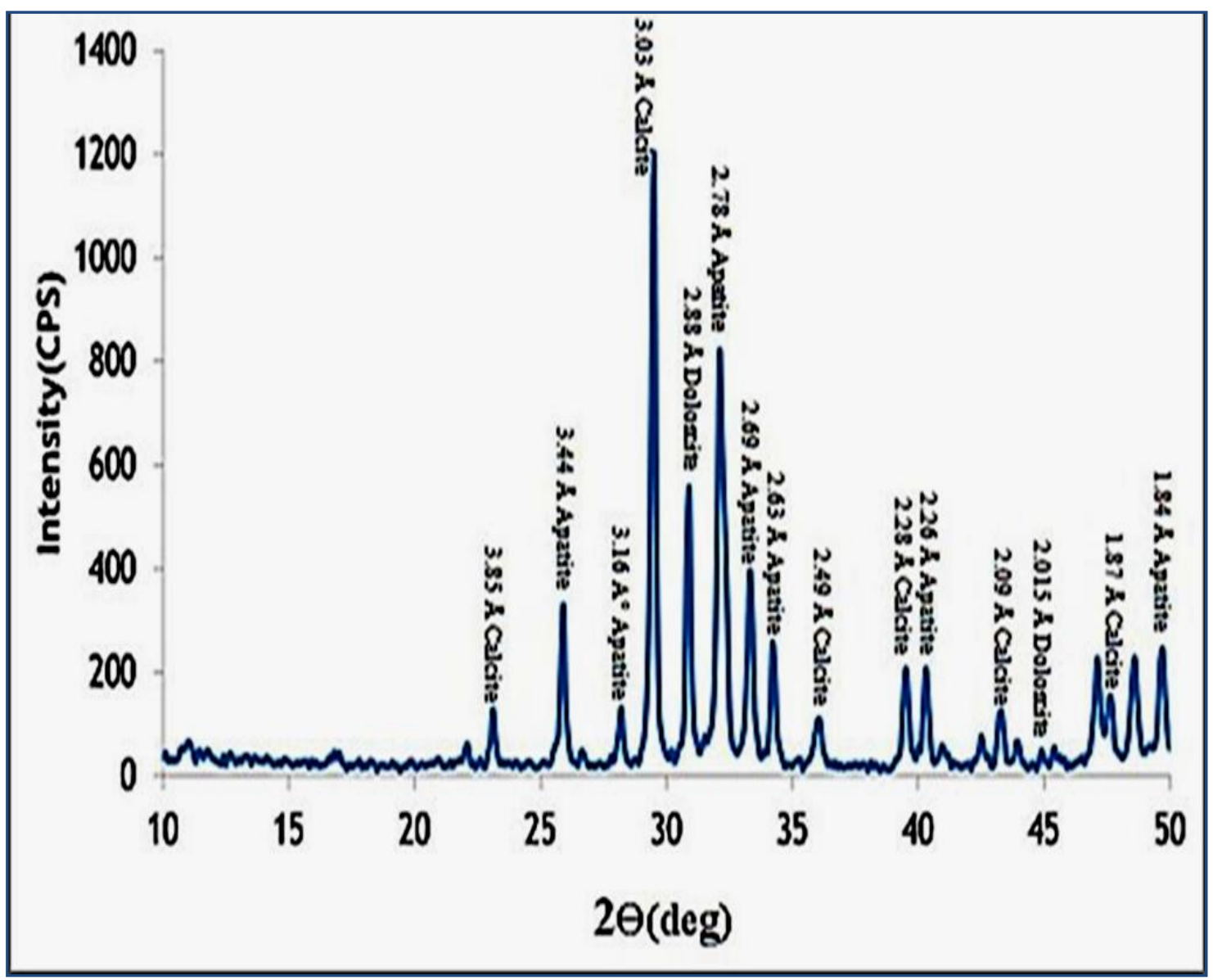

Fig. 5: XRD pattern of examined low-grade phosphate sample before beneficiation. 


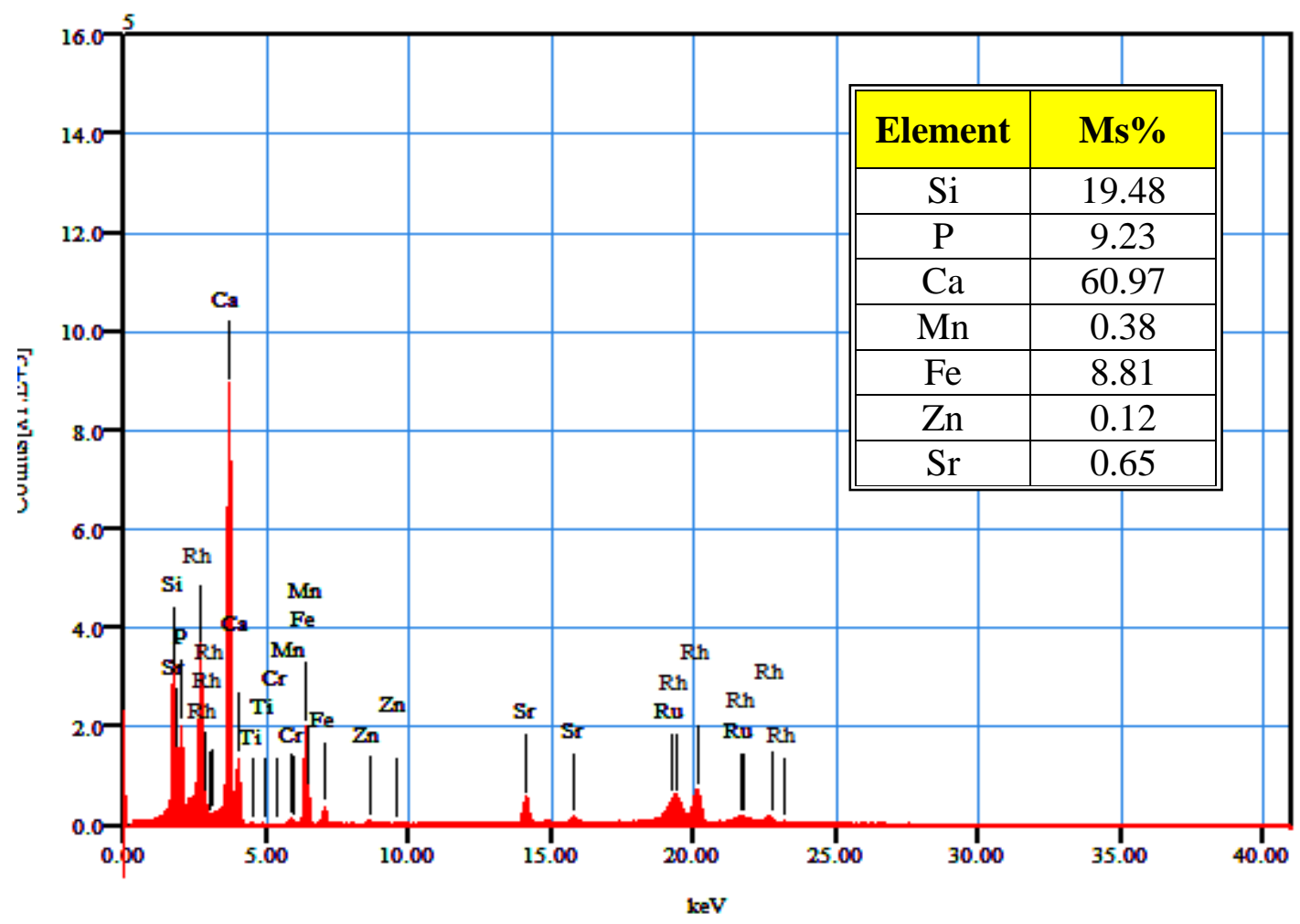

Fig. 6: XRF pattern of the original phosphate sample.

Table (1): Chemical composition of major oxides and trace elements of original sample.

\begin{tabular}{|c|c|c|c|}
\hline Oxides & Content \% & Trace elements & Content (ppm) \\
\hline $\mathrm{P}_{2} \mathrm{O}_{5}$ & 21.14 & $\mathrm{Cr}$ & 40.01 \\
\hline $\mathrm{CaO}$ & 46.68 & $\mathrm{Co}$ & 2.96 \\
\hline $\mathrm{MgO}$ & 3.04 & $\mathrm{Ni}$ & 8.04 \\
\hline $\mathrm{SiO}_{2}$ & 10.63 & $\mathrm{Cu}$ & 11.50 \\
\hline $\mathrm{Na}_{2} \mathrm{O}$ & 0.67 & $\mathrm{Zn}$ & 71.43 \\
\hline $\mathrm{K}_{2} \mathrm{O}$ & 0.42 & $\mathrm{Zr}$ & 31.07 \\
\hline $\mathrm{Al}_{2} \mathrm{O}_{3}$ & 1.35 & $\mathrm{Rh}$ & 89 \\
\hline $\mathrm{Fe}_{2} \mathrm{O}_{3}$ & 2.97 & $\mathrm{Y}$ & 205 \\
\hline $\mathrm{MnO}$ & 0.03 & $\mathrm{Ba}$ & 13.93 \\
\hline $\mathrm{C} 1$ & 0.45 & $\mathrm{~V}$ & 96 \\
\hline $\mathrm{F}$ & 1.27 & $\mathrm{Sr}$ & 353.07 \\
\hline $\mathrm{SO}_{4}$ & 2.11 & $\mathrm{Mn}$ & 822 \\
\hline $\mathrm{L} . \mathrm{O} . \mathrm{I}$ & & $\mathrm{U}$ & 39.99 \\
\hline
\end{tabular}

Then, the phosphate sample was subjected to mechanically eliminating impurities by mean of up current classifiers. The cleaned sample was dried for analysis by XRF . The results are shown in figure 7. Moreover, it appears that the sample contains Si (15.33\%), $\mathrm{P}(11.03 \%), \mathrm{Ca}(56.46 \%), \mathrm{Ti}(0.51 \%), \mathrm{Mn}(0.35 \%), \mathrm{Fe}(6.28 \%)$ and $\mathrm{Sr}(0.76 \%)$. In addition, the chemical analysis of major oxides and trace elements of the improved sample by up current classifiers was done and shown in table 2. 


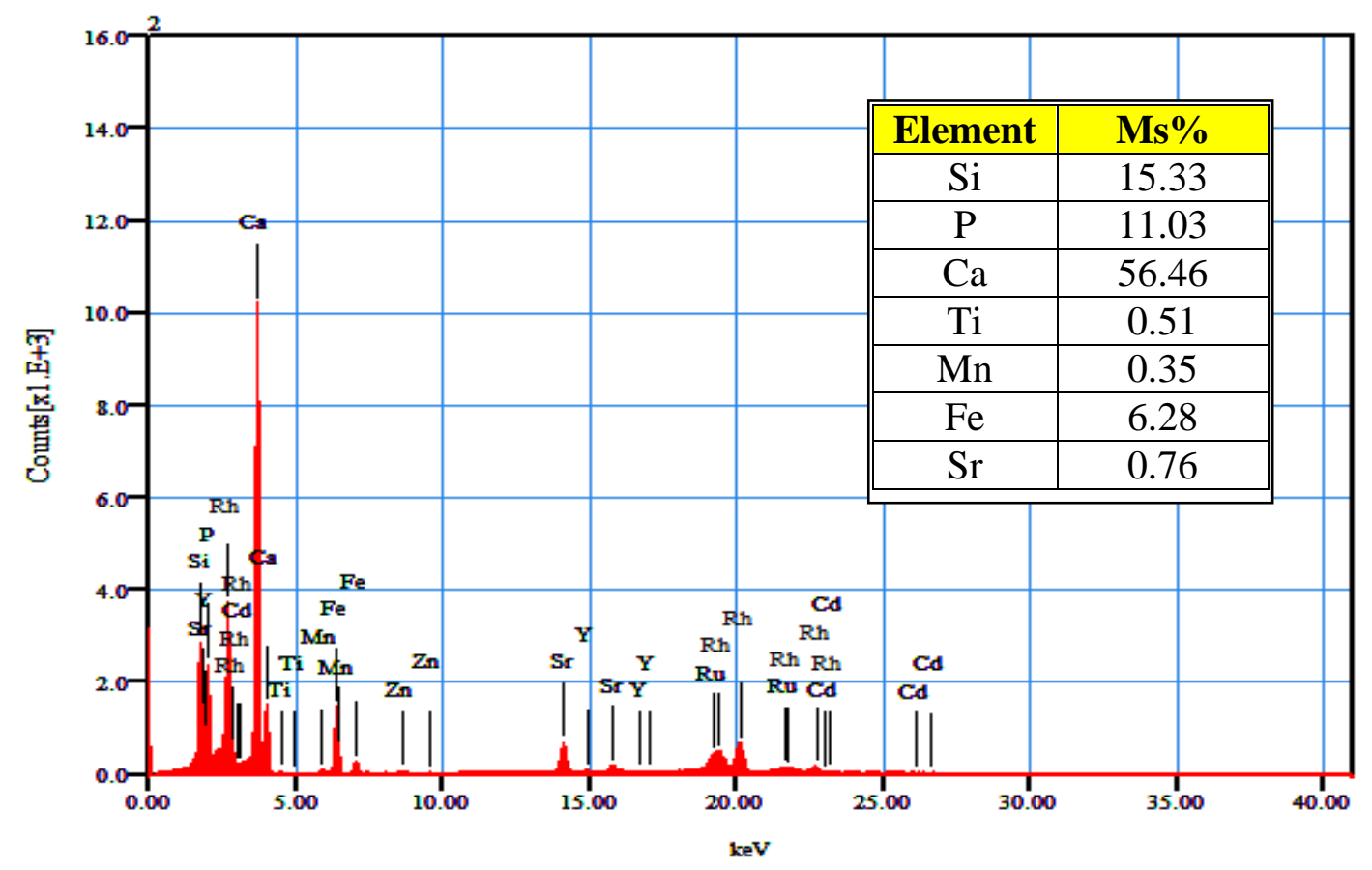

Fig. 7: XRF pattern of the collected sample from the up-current classifier.

Table (2): Chemical analysis of major oxides and trace elements of the improved sample by up current classifiers.

\begin{tabular}{|c|c|c|c|c|c|c|c|c|c|c|c|c|}
\hline Oxides & $\mathrm{P}_{2} \mathrm{O}_{5}$ & $\mathrm{CaO}$ & $\mathrm{MgO}$ & $\mathrm{SiO}_{2}$ & $\mathrm{Na}_{2} \mathrm{O}$ & $\mathrm{K}_{2} \mathrm{O}$ & $\mathrm{SO}_{4}$ & $\mathrm{Al}_{2} \mathrm{O}_{3}$ & $\mathrm{Fe}_{2} \mathrm{O}_{3}$ & $\mathrm{Cl}$ & $\mathrm{F}$ & L.O.I \\
\hline Content\% & 25.30 & 43.61 & 1.73 & 9.21 & 0.56 & 0.25 & 2.80 & 0.41 & 2.64 & 0.51 & 2.10 & 11.20 \\
\hline
\end{tabular}

The phosphate sample was then concentrated by mean of shaking table using different inclination $\mathrm{s}$ and flow rates the best results were at flow rate $1.3 \mathrm{~L} / \mathrm{min}$ and an inclination of 2 degree. the obtained results by XRF indicates that using the shaking table technique improves the $\mathrm{P}$ content from $11.03 \%$ to $12.81 \%$ and reduces the iron content from $(6.28 \%)$ to $(3.92 \%)$ as shown in figure 8 . Also the chemical analysis of major oxides and trace elements of the improved sample by shaking table was don and shown in table 3.

Table (3): Chemical analysis of major oxides and trace elements of the improved Sample by shaking table.

\begin{tabular}{|c|c|c|c|c|c|c|c|c|c|c|c|c|}
\hline Oxides & $\mathrm{P}_{2} \mathrm{O}_{5}$ & $\mathrm{CaO}$ & $\mathrm{MgO}$ & $\mathrm{SiO}_{2}$ & $\mathrm{Na}_{2} \mathrm{O}$ & $\mathrm{K}_{2} \mathrm{O}$ & $\mathrm{SO}_{4}$ & $\mathrm{Al}_{2} \mathrm{O}_{3}$ & $\mathrm{Fe}_{2} \mathrm{O}_{3}$ & $\mathrm{Cl}$ & $\mathrm{F}$ & $\mathrm{L} . \mathrm{O} . \mathrm{I}$ \\
\hline Content\% & $29.33 \%$ & 46.30 & 0.65 & 7.62 & 0.21 & 0.24 & 1.61 & 0.71 & 2.43 & 0.23 & 2 & 10.60 \\
\hline
\end{tabular}




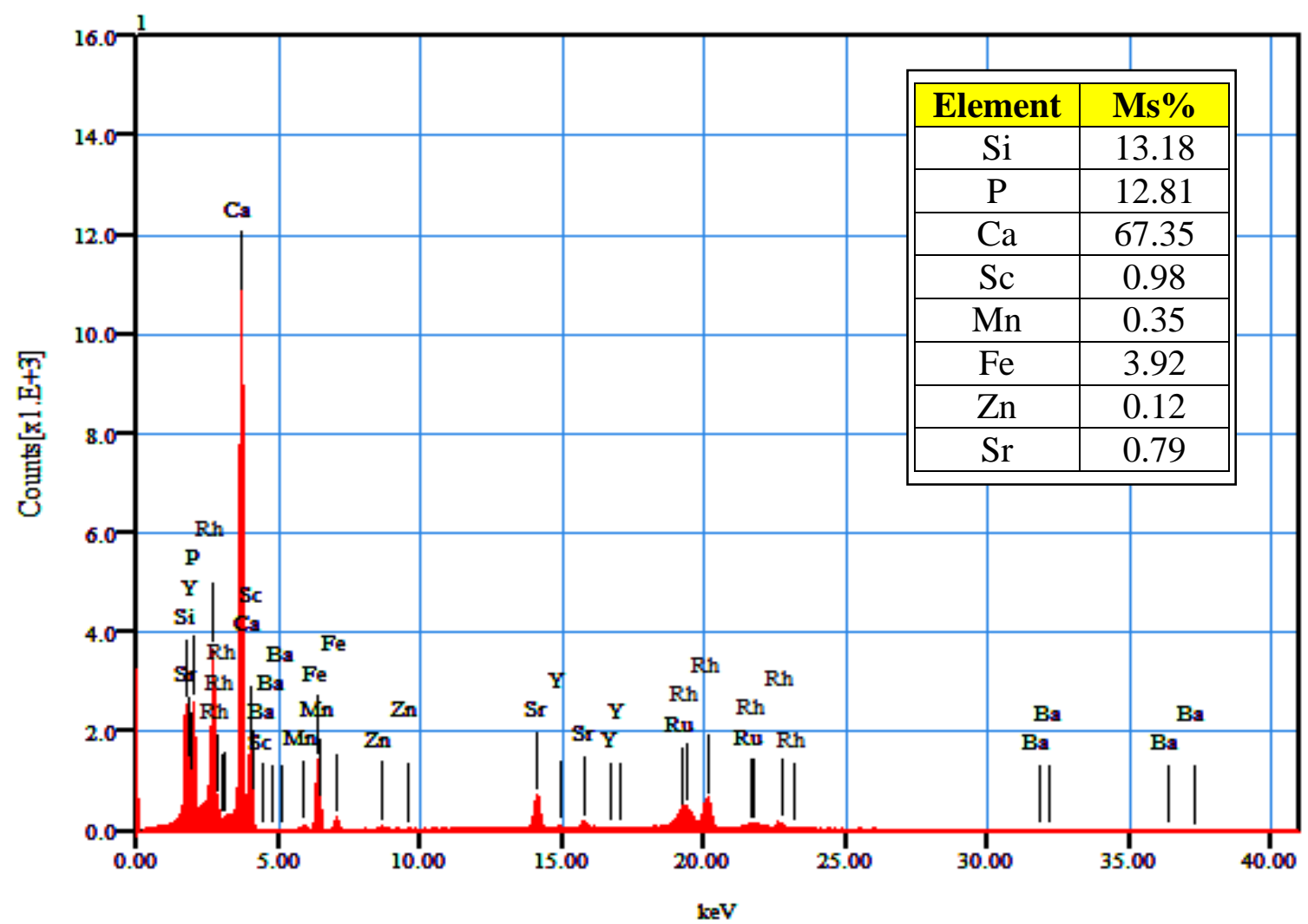

Fig. 8: XRF pattern of the separated sample from the shaking table.

Then the phosphate sample was followed by concentration by hydraulic separation which upgrading of phosphate sample requires partial removal of impurities and other elements that are detrimental to its end use. As a result of using hydraulic separation, three grades of phosphate separated $(\mathrm{A}, \mathrm{B}, \mathrm{C})$ and the obtained results by $\mathrm{X} \mathrm{R} \mathrm{F}$ indicates that using the hydraulic separation technique improves $\mathrm{P}$ content from $12.81 \%$ to $13.50 \%$ in (grade c), to $13.75 \%$ in (grad B) and to $14.68 \%$ in (grade A) as shown in figures 9, 10 and 11. In addition, the chemical analysis of major oxides and trace elements of the improved samples by hydraulic separation was done and shown in tables 4, 5 and 6. Finally, the results of this study led to achieve the desired product (high grade of phosphate) which is imperative to meeting market requirements and to prove the relationship between the uranium concentration and the upgrading of El Sibaeya phosphate ore by physical processes, which indicate that high-grade ore have highly concentration of uranium than low-grade ore. The collected high-grade phosphate, which obtained from the hydraulic separation, contains concentrated uranium (172.12 ppm) that could be directed to leaching and extraction of uranium.

Table (4): Chemical analysis of major oxides and trace elements of concentrate $(\mathrm{C})$.

\begin{tabular}{|c|c|c|c|c|c|c|c|c|c|c|c|c|}
\hline Oxides & $\mathrm{P}_{2} \mathrm{O}_{5}$ & $\mathrm{CaO}$ & $\mathrm{MgO}$ & $\mathrm{SiO}_{2}$ & $\mathrm{Na}_{2} \mathrm{O}$ & $\mathrm{K}_{2} \mathrm{O}$ & $\mathrm{SO}_{4}$ & $\mathrm{Al}_{2} \mathrm{O}_{3}$ & $\mathrm{FeO}_{3}$ & $\mathrm{Cl}$ & $\mathrm{F}$ & $\mathrm{L} . \mathrm{O} . \mathrm{I}$ \\
\hline Content $\%$ & 30.92 & 45.90 & 0.73 & 6.81 & 0.10 & 0.64 & 1.68 & 0.64 & 2.38 & 0.03 & 3.27 & 8.21 \\
\hline
\end{tabular}




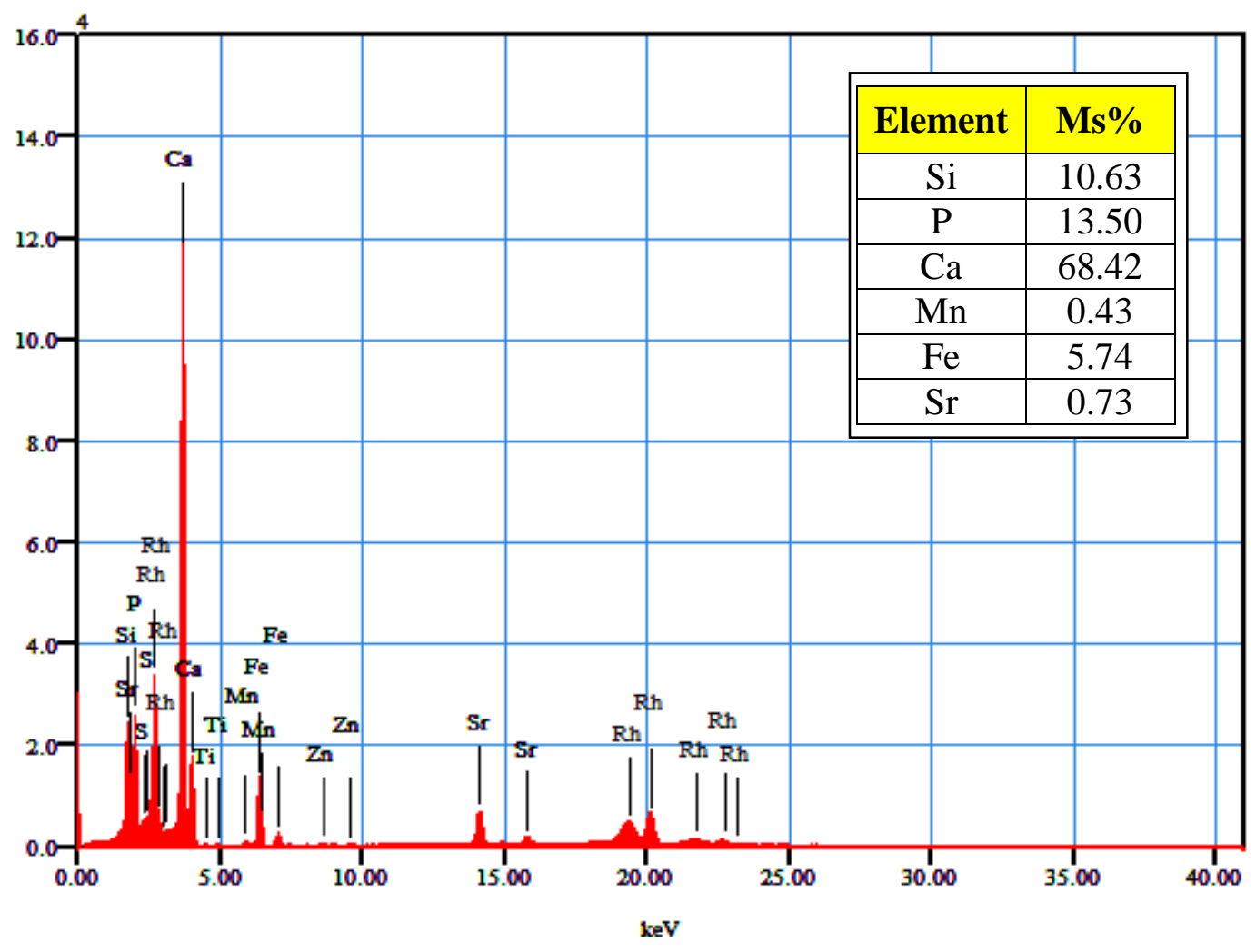

Fig. 9: XRF pattern of concentrate (C) from the hydraulic separation.

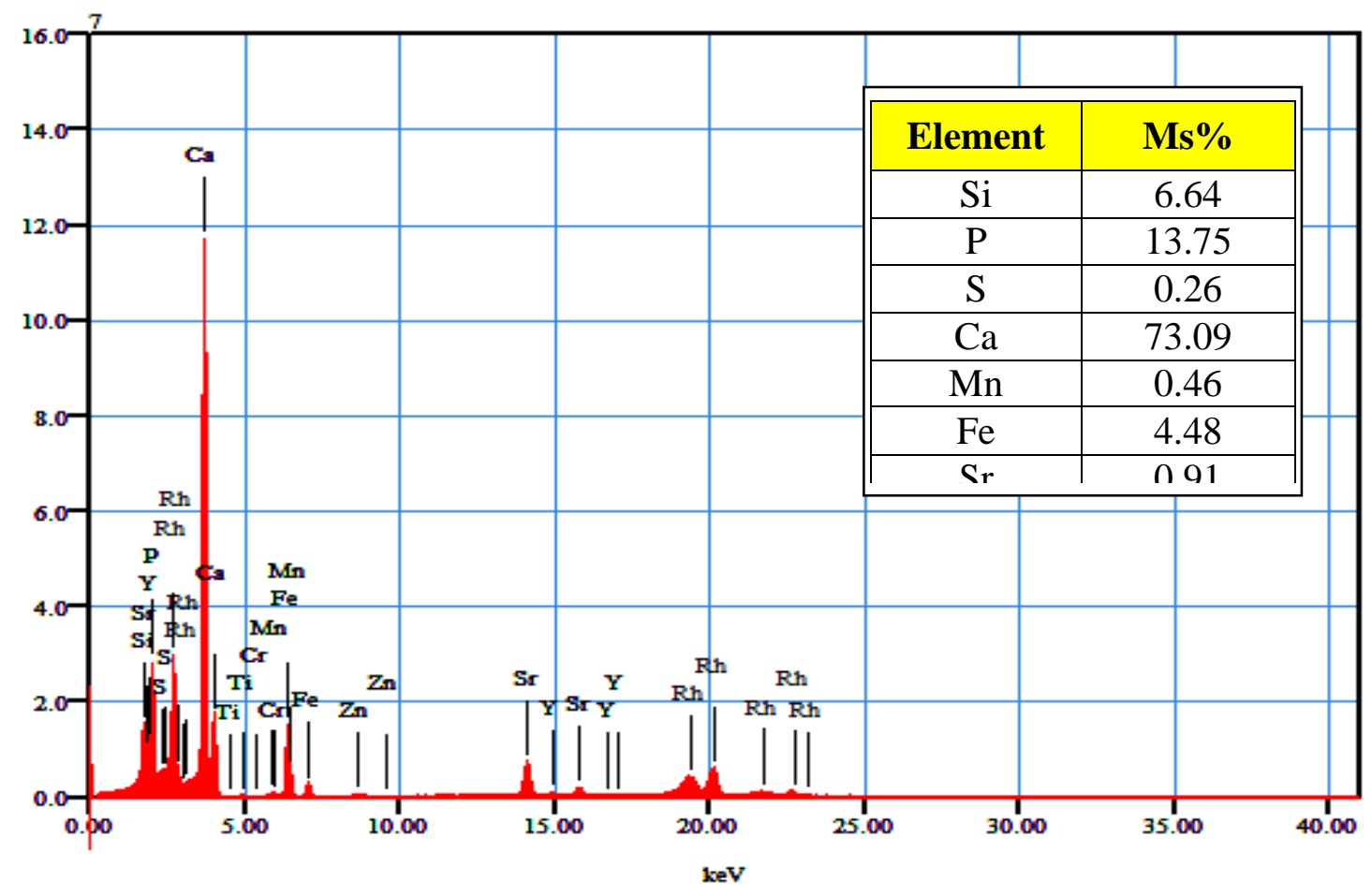

Fig. 10: XRF pattern of concentrate (B) from the hydraulic separation. 
Table (5): Chemical analysis of major oxides and trace elements of concentrate (B).

\begin{tabular}{|c|c|c|c|c|c|c|c|c|c|c|c|c|}
\hline Oxides & $\mathrm{P}_{2} \mathrm{O}_{5}$ & $\mathrm{CaO}$ & $\mathrm{MgO}$ & $\mathrm{SiO}_{2}$ & $\mathrm{Na}_{2} \mathrm{O}$ & $\mathrm{K}_{2} \mathrm{O}$ & $\mathrm{SO}_{4}$ & $\mathrm{Al}_{2} \mathrm{O}_{3}$ & $\mathrm{FeO}_{3}$ & $\mathrm{Cl}$ & $\mathrm{F}$ & L.O.I \\
\hline Content\% & 31.49 & 47.33 & 0.68 & 6.17 & 0.16 & 0.34 & 1.62 & 0.79 & 2.11 & 0.01 & 2.18 & 8.67 \\
\hline
\end{tabular}

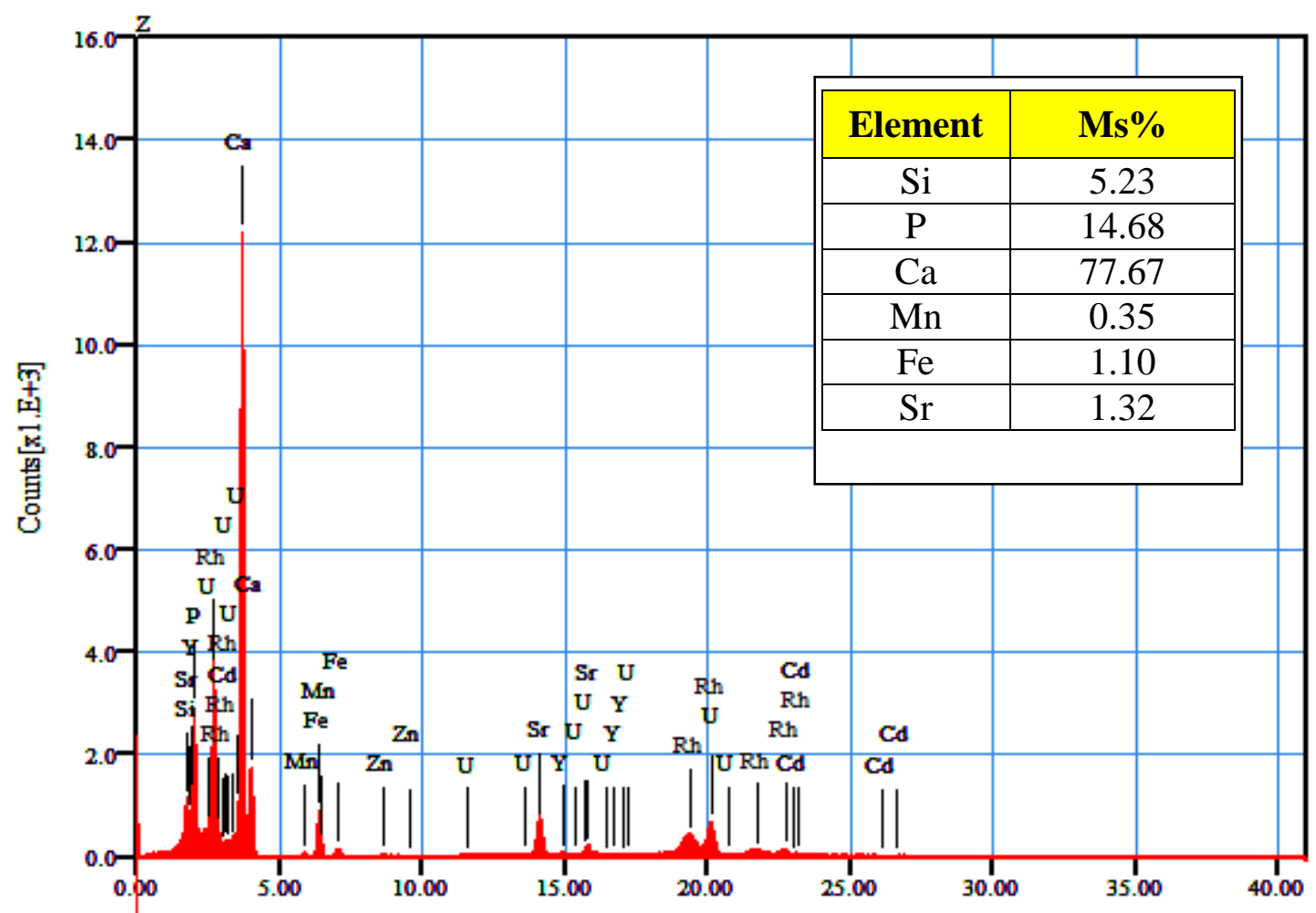

Fig. 11: XRF pattern of concentrate (A) from the hydraulic separation.

Table (6): Chemical analysis of major oxides and trace elements of concentrate (A).

\begin{tabular}{|c|c|c|c|}
\hline Oxides & Content\% & Trace elements & Content (PPM) \\
\hline $\mathrm{P}_{2} \mathrm{O}_{5}$ & 33.63 & $\mathrm{Cr}$ & 36 \\
\hline $\mathrm{CaO}$ & 47.66 & $\mathrm{Co}$ & 9 \\
\hline $\mathrm{SiO}_{2}$ & 4.91 & $\mathrm{Ni}$ & 6.93 \\
\hline $\mathrm{Fe}_{2} \mathrm{O}_{3}$ & 1.25 & $\mathrm{Cu}$ & 8.74 \\
\hline $\mathrm{Al}_{2} \mathrm{O}_{3}$ & 0.64 & $\mathrm{Zn}$ & 66.34 \\
\hline $\mathrm{MgO}$ & 0.57 & $\mathrm{Zr}$ & 28.76 \\
\hline $\mathrm{Na}_{2} \mathrm{O}$ & 0.49 & $\mathrm{Rh}$ & 103.01 \\
\hline $\mathrm{K}_{2} \mathrm{O}$ & 0.89 & $\mathrm{Y}$ & 149.31 \\
\hline $\mathrm{F}$ & 1.89 & $\mathrm{Sr}$ & 342.09 \\
\hline $\mathrm{Cl}$ & 1.74 & $\mathrm{Mn}$ & 744.19 \\
\hline $\mathrm{SO}_{4}$ & 1.07 & $\mathrm{U}$ & 172.12 \\
\hline $\mathrm{L.O.I}$ & 9.27 & & \\
\hline
\end{tabular}


Table (7): The products that have been attained from

low-grade Egyptian phosphate ore.

\begin{tabular}{|c|c|c|}
\hline Product & Quantity & Percentage \\
\hline Slime & $2948.35 \mathrm{gr}$ & $29 \%$ \\
\hline $\mathrm{P}_{2} \mathrm{O}_{5}(33.63 \%)$ & $3275.37 \mathrm{gr}$ & $33 \%$ \\
\hline $\mathrm{P}_{2} \mathrm{O}_{5}(31.49 \%)$ & $1262.66 \mathrm{gr}$ & $31 \%$ \\
\hline $\mathrm{P}_{2} \mathrm{O}_{5}(30.92 \%)$ & $908.62 \mathrm{gr}$ & $9 \%$ \\
\hline Loss & 693 & $7 \%$ \\
\hline Tailing & 912 & $9 \%$ \\
\hline
\end{tabular}

\section{CONCLuSiON}

The present work is mainly concerned with the improvement of low-grade Egyptian phosphate ore $\left(21.14 \% \mathrm{P}_{2} \mathrm{O}_{5}\right)$ from East Sibaeya area. Upgrading the phosphate rock is done through crushing, Screening, Up-current classifiers, gravimetric separation and hydraulic separation. The results of this work led to achieve the desired product (highgrade of phosphate), which is imperative to market requirements and to prove the relationship between the uranium concentration and the upgrading of El-Sibaeya phosphate ore by physical processes which indicate that high-grade ore have highly concentration of uranium than low-grade ore. At optimum conditions gave a product, which analyzed $\mathrm{P}_{2} \mathrm{O}_{5}$ (33.63\%), $\mathrm{CaO}$ (47.66\%), $\mathrm{SiO}_{2}$ (4.91\%), $\mathrm{Fe}_{2} \mathrm{O}_{3}(1.25 \%), \mathrm{Al}_{2} \mathrm{O}_{3}$ (0.64\%), $\mathrm{MgO}(0.57 \%), \mathrm{Na}_{2} \mathrm{O}(0.49 \%), \mathrm{K}_{2} \mathrm{O}$ (0.89\%), $\mathrm{F}(1.89 \%), \mathrm{Cl}(1.74 \%), \mathrm{SO}_{4}$ (1.07\%) and $\mathrm{U}(172.12 \mathrm{ppm})$.

\section{REFERENCES}

[1] Anon: "Classifiers part 2: Some of the major manufacturers of classification equipment used in mineral processing". Mining Mag., 40, July (1984).

[2] Abouzeid, A. Z. M.: "Physical and thermal treatment of phosphate ores-an overview". Int. J. Miner process. 85, 59-84, (2008).

[3] Gresshaber, H. E.: "Crushing and grinding; design considerations". World mining 36, 41, Oct. (1983).

[4] Grieco, F. W. and Grieco, J. P.: "Manufacturing and refurbishing of jaw crushing". CIM Bulletin, 78, 38, Oct. (1985).

[5] Manser, R. J. et al.: "The shaking table concentrator the influence of operating condition and table parameters on mineral separation - the development of a mathematical model for normal operating conditions". Minerals engineering 4 (3/4)369, (1991).

[6] Sivamohan, R., and Forssberg, E.: "Principle of tabling". Int. J. Min. Proc.15, 28, Nov. (1985).

[7] Sharam, S.; Aisan, R. and Armin, S.: "Beneficiation of low-grade phosphate deposits by a combination of calcination and shaking tables". Southwest Iran, Minerals.5, 367-379, (2015).

[8] Terry, R. L.: "Minerals concentration by wet tabling, minerals processing 15". 14., July/Aug. (1974).

[9] Wills, B. A.: "Laboratory simulation of shaking table performance". Min. Mag. 489, June (1981).

[10] Wills, B. A.: "Mineral processing technology". $4^{\text {th }}$ ed., Pergamon press., (1988).

[11] Wills, B. A.: "Mineral processing technology". $5^{\text {th }}$ ed., Pergamon, Oxford, (1992). 


\section{الملخص العربي}

بعتبر الفوسفات أحد الخامات الهامة في مصر نظر آ لكثرة استخداماته في العديد

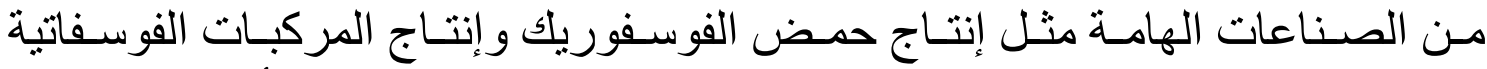
الكيميائيـة. هذا بالإضـافة إلى إمكانيـة تركيز و اسـتخلاص العناصـر الأرضية النـادرة و المشعة. لذلك عمل هذا البحث على كيفيـة تطبيـق طرق جديدة من التركيز الفيزيـائي

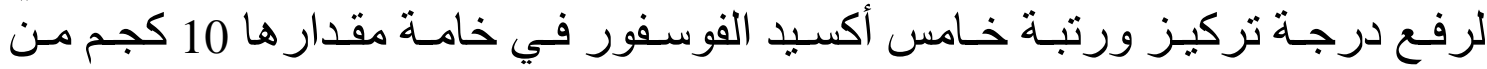
فوسفات شرق السباعية (P2 هذا البحث على إيجاد العلاقة بين نركيز اليور انيوم ورفع درجة تركيز

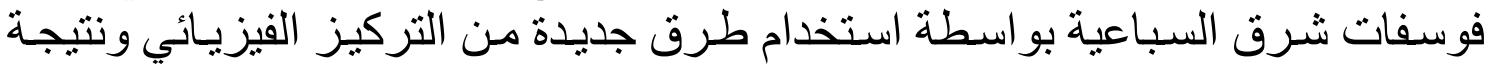

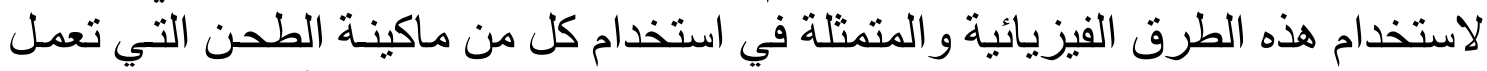

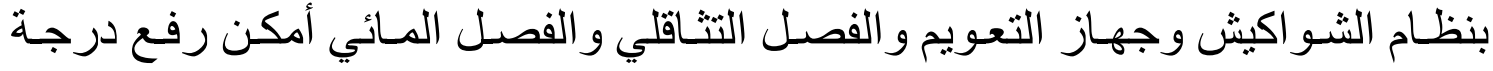
تركيز

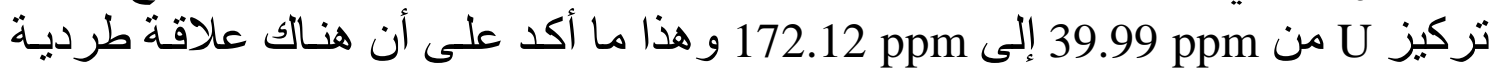
بين رفع درجة تركيز P ودرجة تركيز Uي في خامة فوسفات شرق السباعية. 